Canadian Studies in Population, Vol. 34.2, 2007, pp. 129-148

\title{
Educational Selectivity of Out-migration in Canada: 1976-1981 to 1996-2001
}

\section{Bali Ram}

Y. E. Shin

Demography Division

Statistics Canada

Ottawa, Ontario, Canada K1A 0T6

rambali@statcan.ca

\begin{abstract}
The major objective of this paper is to show that migrants are positively selected whether they are driven by economic factors or by non-economic factors, and whether they are motivated by pull factors or push factors. Using "five-year migration data" from the 1981 to 2001 censuses of Canada, we find that the education gradient of out-migration is apparent in every region, with the highly educated being more mobile than the less educated. However, the pattern is most pronounced in the Atlantic region, Quebec, and Manitoba/Saskatchewan, the regions experiencing poorer economic conditions and persistent net losses through migration. The three high-income provinces, Ontario, Alberta, and British Columbia not only experience lower overall net losses, but are also less likely to lose their better educated persons-even during bad economic times. Quebec emerges as a special case where economic as well as linguistic-political factors play an important role in governing the out-migration patterns of the better educated, particularly those belonging to the non-Francophone group.
\end{abstract}

Key Words: Inter-provincial migration, out-migration rate, Canadian migration patterns, Quebec's migration. 
Bali Ram and Y. E. Shin

\section{Résumé}

L'objectif principal du présent document est de montrer que les migrants font l'objet d'une sélection positive, qu'ils soient motivés par des facteurs économiques ou non économiques, ou par des facteurs d'attirance ou d'incitation. En utilisant les données quinquennales sur la migration tirées des recensements du Canada de 1981 à 2001, nous constatons que le gradient de scolarité lié à l'émigration interne est apparent dans chaque région, les personnes très instruites étant plus mobiles que celles qui sont moins instruites. Toutefois, la tendance est plus prononcée dans la région de l'Atlantique, au Québec et au Manitoba/Saskatchewan, soit les régions qui connaissent une conjoncture économique moins favorable et des pertes nettes persistantes résultant de la migration. Les trois provinces prospères, l'Ontario, l'Alberta et la Colombie-Britannique, en plus de subir des pertes nettes globales inférieures, sont moins susceptibles de perdre leurs citoyens les plus instruits, même en période économique difficile. Le Québec ressort comme un cas spécial, où les facteurs économiques et linguistico-politiques jouent un rôle important dans la détermination des tendances en matière d'émigration interne des personnes les plus instruites, particulièrement celles qui appartiennent au groupe non francophone.

Mots-clés : migration interprovinciale, taux d'émigration interne, tendances migratoires au Canada, migration du Québec.

\section{Introduction}

Migration is inextricably linked to the superior social and economic advancements of the migrants and their families as well as to the regions they move into. There is something unique about migration or about migrants that promotes success (Blau and Duncan, 1967:243-275). Migration has often been viewed as an investment and therefore, both migrants and the places of destination are expected to gain from moving (Greenwood, 1975, 1985; Sahota, 1968; Sjaastad, 1962). Migration leads to greater occupational success and increased income, leaving migrants and places of destination better off than nonmigrants and the places of origin. Persons who live outside the region of their birth tend to achieve higher social and economic status than those who have remained in it. Therefore, regions that gain in population as a result of interregional migration experience a favourable change in their population composition with respect to education and skills (Stone, 1969, 1979). 
However, migrants are not a random sample of population. As Ravenstein (1889) posited in his famous essay on the "laws of migration", migrants are a differentially selected group of persons at both the places of origin and the destination. Migration is selective because persons respond differently to factors which are attractive or repulsive to them at the points of origin and destination, and also because they have different abilities to overcome the obstacles between the points of origin and destination (Lee, 1966). When migration is stimulated by economic growth, migrants tend to be positively selected, with a larger representation of persons with better human capital characteristics (such as education, training, experience, and skills). Among such characterises, education is perhaps the best observed predictor of migration, better than even income and occupation (Lansing and Muller, 1967; Long, 1973, 1988; Ritchey, 1976). However, as Greenwood (1997) asserts, the positive relationship between education and migration is one of the "most universal" but "less-well documented" observations in the literature on geographic mobility in developed countries. Studies suggest that in any time or place, it is the better educated who are most likely to migrate (Greenwood, 1975, 1997; Levy and Wadycki, 1974; Long, 1973, 1988: 92-97; Schwartz, 1973, 1976; Stone, 1969, 1978).

Migrants are positively selected even when migration is stimulated by economic stagnation. For example, the unemployment rate does not necessarily influence the out-migration of less educated and less skilled persons, despite the fact that they are the ones who have the highest unemployment rate. Rather, it serves as a push factor that encourages persons to move if they are well educated and skilled (Lansing and Muller, 1967; DaVanzo, 1978). Consequently, regions tending to stagnation lose the younger, better-educated and skilled segments of their population first, which produces an unfavourable change in population composition (Cadwallader, 1992:9).

There are a number of explanations for the greater geographic mobility of the better educated. Economic explanations, which are usually derived from the human capital model, dominate much of the research on this subject. According to this model, migration is an investment in human capital and individuals move primarily for economic gains (DaVanzo, 1983; Sahota, 1968; Sjaastad, 1962). Most individuals move from lower-income regions to higher-income regions because they expect the benefits to outweigh the costs. This phenomenon is particularly pronounced for the better educated, who benefit much more from moving than the less educated. Better educated persons move at a higher rate than the less educated persons because their opportunities are more national in scope. Moreover, their chances of being unemployed in any location is relatively less, because their skills are more substitutable than those of less educated (Schwartz, 1971; 1973). Educated persons can take lower paying jobs available to less educated persons if they do not receive their expected wage, but the 
converse is not true (Levy and Wadycki, 1974). Also, they are better able to calculate the economic and psychic costs associated with moving to a new destination and to invest in the search for better opportunities (DaVanzo, 1983; Levy and Wadycki, 1974; Schwartz, 1976).

According to socio-psychological models, educated persons are better informed about the place of destination and better able to process information efficiently. Less educated individuals tend to return quickly, presumably because they are correcting earlier mistakes made due to faulty interpretations of information (DaVanzo, 1983). Also, they do not find "intervening obstacles" to be of much importance when making a decision to move. For example, educated persons are more likely to move longer distances, whereas less educated persons move within their own neighbourhoods or localities familiar to them (Courchene, 1970; Schwartz, 1973). In general, there is a direct association between distance and the quality of migrants (Lee, 1966). The better educated are not as deterred by the psychic costs involved in moving as are the less educated. It happens primarily because educated persons are less attached to traditional surroundings and more receptive to a new environment (Levy and Wadycki, 1974; Schwartz, 1973).

The positive selectivity of internal migration is likely to be highly pronounced in a country such as Canada, which exhibits large regional economic disparity. Over the past several decades the average income has been always lower for the Atlantic region, Quebec, Manitoba and Saskatchewan and higher for Ontario, British Columbia and Alberta (Figure 1). Since migration is selective of younger, better educated and more productive workers, one expects them to move away from regions of weak labour demand to regions of greater labour demand, which offer greater economic gains. Also, during periods of economic expansion, on average, migrant flow is expected to be of poorer quality while during periods of relatively poor economic conditions, the migration flow is expected to be of better quality ${ }^{1}$ (Greenwood, 1997). Canadian researchers devoted a good deal of attention to this subject in the 1970s and 1980s (Courchene, 1970. 1974; Marr and Millard, 1980; McInnis, 1969; Robinson and Tomes, 1982; Stone, 1969, 1978, 1979; Vanderkamp, 1973), but studies have been relatively scarce in recent years even though more and better data have become available (but see Day and Winer, 2001; Finnie, 1999, 2000; Hou and Beaujot, 1995). The present study is an attempt to partially fill in this gap by examining quinquennial census data on out-migration rates by education from 1976-1981 through 1996-2001 for six regions: the Atlantic provinces, Quebec, Ontario, Manitoba/Saskatchewan, Alberta and British Columbia. For the sake of simplicity, we focus primarily on the out-migration rates for persons in the age group, 25-44, most of whom are presumed to have completed their education and belong to a highly mobile category. 
Educatiional Selectivity of Out-migration in Canada: 1976-1981 to 1996-2001

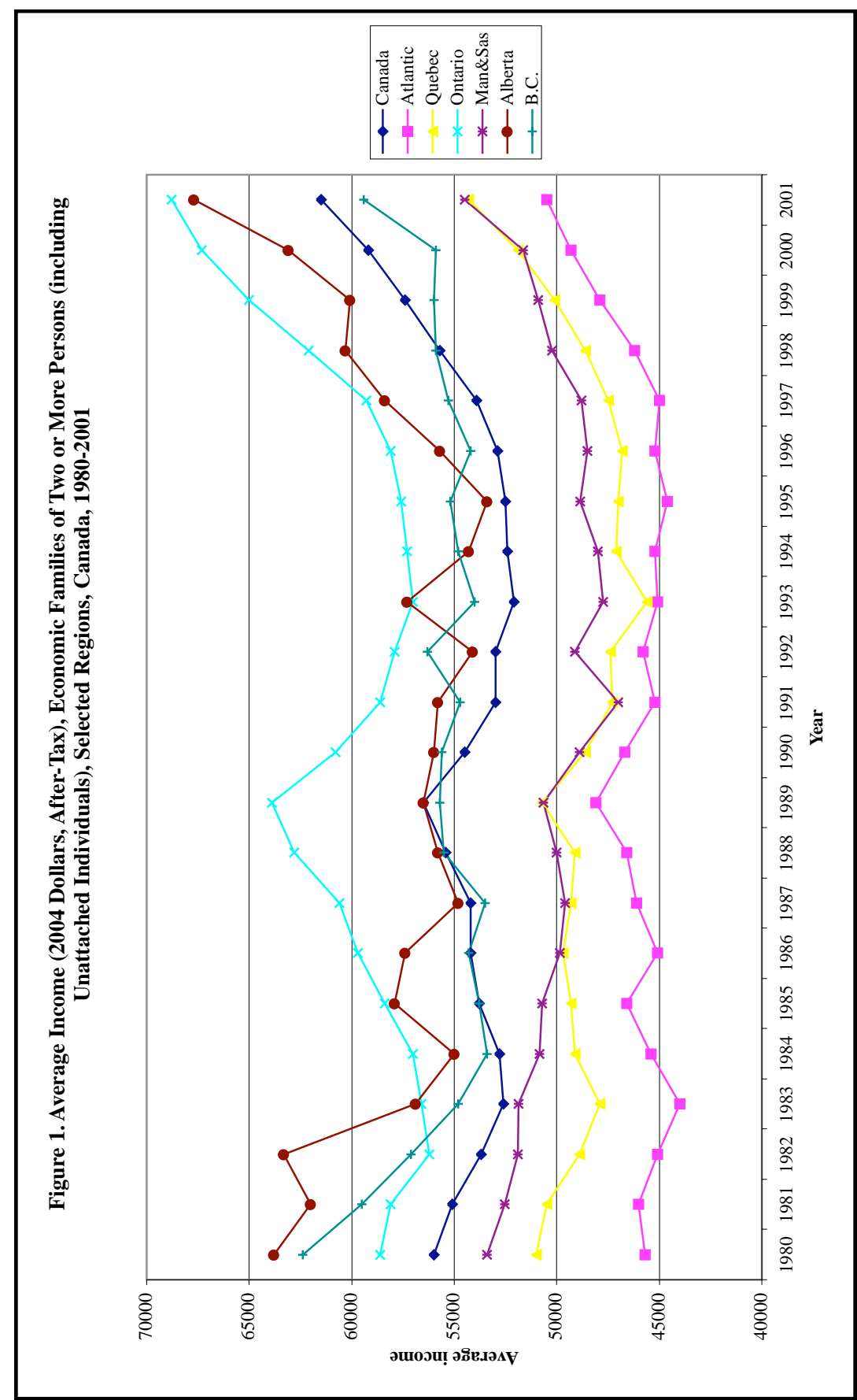




\section{Data and Methods}

Migration data have been collected in the Census of Canada since 1961. This paper uses the data on interprovincial migration, which is measured by comparing a person's usual place of residence on census day with the residence on the same day five years earlier. If someone's place of residence five years prior to the census is different from his/her residence on census day in terms of municipality, then this person is designated as a migrant. ${ }^{2}$ Thus, the data derived for a given census refer to migrations that took place during five years preceding the census (for example, during 1996-2001, in the case of the 2001 census). Analyses presented in this paper cover migration data from 1976-1981 (1981 census) through 1996-2001 (2001 census). These data were retrieved from special tabulations from various censuses.

Education refers to the level that is reported by the respondent in the census. An analysis of migration by education is not fully satisfactory for examining migration selectivity because for certain individuals, particularly those in younger ages, migration may have taken place before the reported level of education was obtained. However, education remains one of the key variables for studying migration selectivity.

Since the number of migrants for certain provinces or territories is too small for a meaningful analysis of the characteristics of migrants, we examine data for the Atlantic region (Newfoundland, Prince Edward Island, Nova Scotia, and New Brunswick), Ontario, Quebec, Manitoba/Saskatchewan, Alberta, and British Columbia and exclude the territories. Primarily, we focus on the out-migration rate which was derived by dividing the number of out-migrants in a given region by the population at risk in the same region. The population at risk was obtained by subtracting the in-migrants and adding the out-migrants over the previous five years to the population at the census date (Long, 1988).

\section{Overall Migration Patterns}

Figure 2 shows net migrations for six regions over the past five intercensal periods, from 1976-1981 through 1996-2001. Overall, only a few regions gain at the expense of most others. There are three broad net migration patterns. The first one is characterized by chronic losses experienced by the Atlantic region, Quebec, Manitoba and Saskatchewan. The net losses of the Atlantic region can be attributed to its relatively sluggish economy. On most socioeconomic measures, whether it is unemployment, income or education, the Atlantic region generally lags behind the other regions. Newfoundland especially sticks out, with the lowest gross national product per capita and highest unemployment rate 
Educatiional Selectivity of Out-migration in Canada:

1976-1981 to 1996-2001

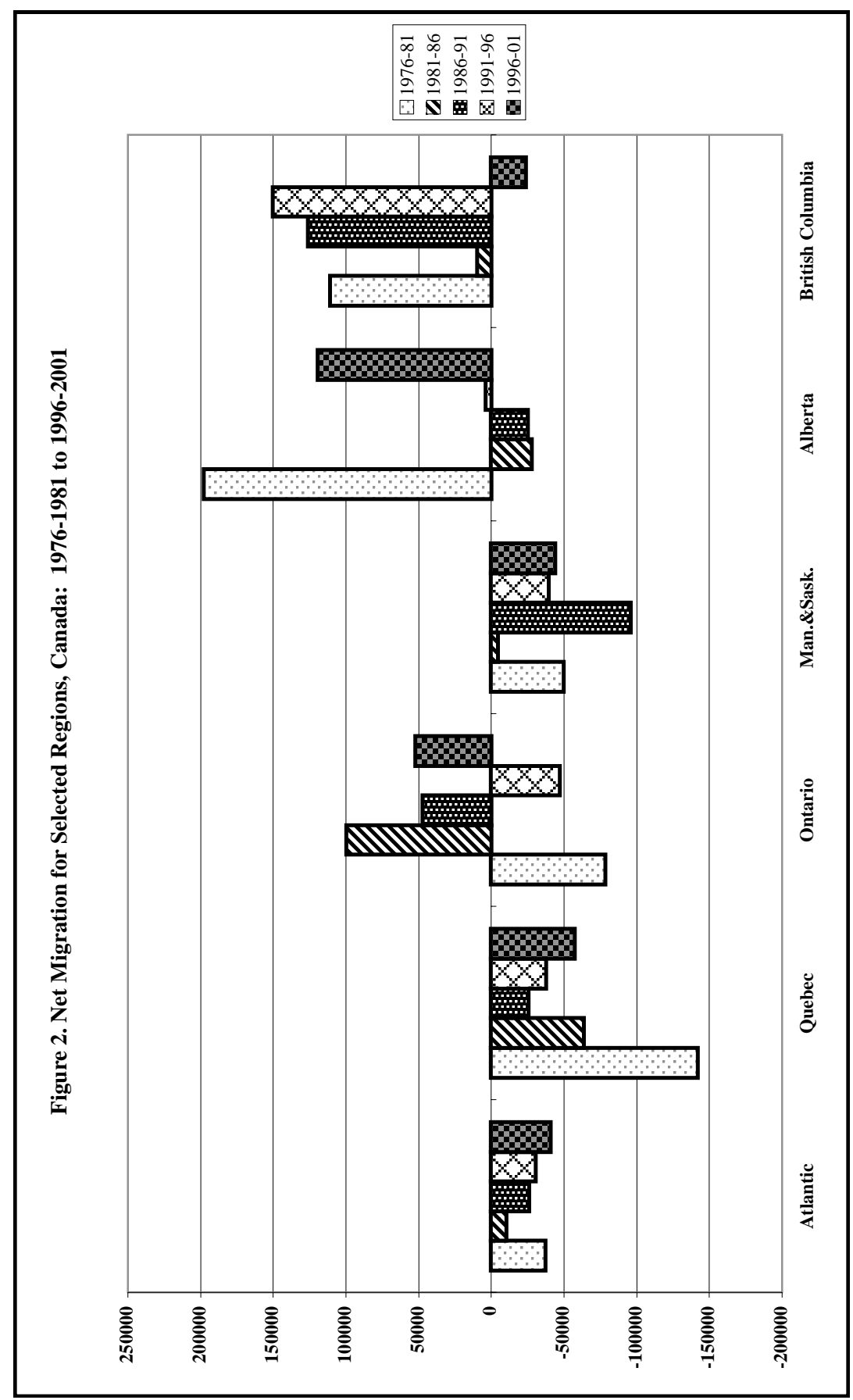

CSP 2007, 34.2: 129-148 
in the country, and with high government transfers. Manitoba and Saskatchewan also display poorer economic conditions and experience a much higher outmigration rate.

Quebec has also experienced continuous net out-migration. Its linguistic boundaries and nationalism in addition to economic uncertainty are primarily behind its constant losses. Since the 1950s, Quebec has been losing population through interprovincial migration almost every year, especially through an outmigration of non-Francophones to other parts of Canada. The resurgence of its sovereignty movement in the early 1970s, the election victory of the Parti Quebecois-a separatist political party—in 1976 and again in 1995, and the introduction of Bill 101 (the French Language Charter) in 1977, have acted as a constant non-economic push to many. However, the role of higher rates of unemployment in Quebec and fewer economic opportunities can not be deemphasised. A rather dramatic shift in Quebec's migration patterns occurred following the 1976 election of the Parti Québécois and the introduction of Bill 101 in 1977 (Marmen and Corbeil, 2004:102-107). The Bill allowed attendance at English schools only to those children whose parents had themselves attended an English school in Quebec. The immediate demographic response to these political events has not only reduced in-migration to Quebec from other provinces, but also encouraged a large out-migration (Ram and Shin, 2000). Since then its net loss through out-migration has slowed down considerably. It moved up slightly during the 1996-2001 period, following the latest sovereignty referendum.

At the other extreme is British Columbia which has experienced persistent gains through interprovincial migration, except for the latest intercensal period (19962001) when the province recorded a net loss. A relatively robust economy and warmer climate are probably the major reasons for these patterns. Somewhere in the middle are the experiences of Ontario and Alberta, which do not show a systematic pattern. Because of their volatile economic conditions, they have gained some times and lost at other times. During its oil boom in 1976-81, Alberta experienced a large net gain, primarily at the expense of Ontario (Ram, Shin, and Pouliot, 1994). During the following two intercensal periods, when Alberta experienced a slump in its oil industry, it experienced a net loss, while Ontario gained. Most recently during 1996-2001, both provinces recorded net gains, with Alberta taking a big lead, particularly at the expense of the neighbouring Manitoba/Saskatchewan and British Columbia. 


\section{Educational Selectivity of Migration}

Against the above background, we examine the educational selectivity of migrants. Table 1 presents the out-migration rate by education and age group for the six regions for the 1996-2001 period. In every age group, university educated persons are the most migratory, followed by those with some postsecondary education and those with 9 to 12 years of schooling, whereas persons with less than grade 9 are the least migratory. Younger people who are highly educated move in search of better job opportunities, whereas older and highly educated people move in search of a better place for retirement or return to their place of origin. However, certain deviations from this general pattern do exist. In Ontario and British Columbia, for example, the least educated persons 15-24 years old are not necessarily the least migratory; in fact, their outmigation rate is higher than those with 9 to 12 years of schooling. Also, the association between education and migration tends to weaken with advancing age, particularly in the regions that have experienced high net gains. British Columbia's experience is especially noteworthy, where virtually no relationship between education and migration exists in the age groups 45-64 and 65 years and over. It is possible that regardless of their educational level, older people prefer to stay there rather than move.

As shown in Figure 3, the education gradient of migration is apparent in every region, although it is most pronounced in the Atlantic region, Manitoba/Saskatchewan, where out-migration in general and among the highly educated is much higher than among the less educated. Quebec exhibits a lower migration rate in general, but relatively high out-migration among the university educated. However, the education gradient is not as prominent in the three highest income provinces, Ontario, Alberta, and British Columbia.

Figure 4 extends the above analysis by presenting out-migration rates for university educated persons in the age group 25 to 44 for five intercensal periods, from 1976-1981 to 1996-2001. The pattern of educational selectivity of migration is most pronounced in the Atlantic region, Manitoba and Saskatchewan. During every intercensal period, the out-migration rate for university educated persons in these regions is high, exceeding 150 per 1,000, an observation highly consistent with the hypothesis concerning the push factors of migration that result from the sluggish economic conditions at the place of origin. At the other extreme are Ontario and British Columbia, with very low out-migration rates of university educated people. Interestingly, in these provinces the low out-migration rates persisted during the times when they attracted a large number of migrants, and also during the times when they lost a large number of people. Ontario's highest out-migration of university educated people occurred during 1976-81 when the province experienced a large 
Bali Ram and Y. E. Shin

Table 1

Out-migration Rate (per 1000) by Age Group, Education and Region, 1996-2001

\begin{tabular}{|c|c|c|c|c|c|}
\hline Region/Education & $15-24$ & $25-44$ & $45-64$ & $65+$ & $15+$ \\
\hline \multicolumn{6}{|l|}{ Atlantic } \\
\hline 0 - 8 years & 62.90 & 38.68 & 16.35 & 8.70 & 17.56 \\
\hline 9 - 13 years & 72.82 & 64.41 & 26.31 & 12.73 & 47.85 \\
\hline Some post secondary & 120.16 & 98.32 & 33.94 & 17.58 & 75.24 \\
\hline University degree & 205.03 & 206.36 & 52.91 & 41.75 & 147.28 \\
\hline Total Education & 98.53 & 104.83 & 31.40 & 13.88 & 67.59 \\
\hline \multicolumn{6}{|l|}{ Quebec } \\
\hline 0 - 8 years & 5.44 & 8.70 & 3.39 & 3.46 & 8.70 \\
\hline $9-13$ years & 18.50 & 14.67 & 7.92 & 9.85 & 12.73 \\
\hline Some post secondary & 15.30 & 21.28 & 12.61 & 16.00 & 17.58 \\
\hline University degree & 45.95 & 54.75 & 21.59 & 27.89 & 41.75 \\
\hline Total Education & 17.75 & 25.70 & 10.73 & 9.03 & 13.88 \\
\hline \multicolumn{6}{|l|}{ Ontario } \\
\hline 0 - 8 years & 22.14 & 20.25 & 7.72 & 4.93 & 7.98 \\
\hline 9 - 13 years & 16.12 & 17.33 & 9.67 & 6.61 & 13.17 \\
\hline Some post secondary & 25.06 & 23.54 & 13.47 & 9.56 & 19.29 \\
\hline University degree & 35.97 & 38.35 & 18.94 & 15.74 & 30.32 \\
\hline Total Education & 20.34 & 25.43 & 12.72 & 7.63 & 18.08 \\
\hline \multicolumn{6}{|c|}{ Manitoba and Saskatchewan } \\
\hline 0 - 8 years & 33.85 & 32.45 & 21.84 & 18.34 & 21.88 \\
\hline $9-13$ years & 64.22 & 58.56 & 32.58 & 24.68 & 48.03 \\
\hline Some post secondary & 105.38 & 87.19 & 45.57 & 30.05 & 71.19 \\
\hline University degree & 180.34 & 177.82 & 72.75 & 56.01 & 133.21 \\
\hline Total Education & 81.95 & 92.45 & 43.00 & 25.54 & 65.02 \\
\hline \multicolumn{6}{|l|}{ Alberta } \\
\hline 0 - 8 years & 39.42 & 40.52 & 26.84 & 15.82 & 24.12 \\
\hline $9-13$ years & 40.89 & 48.90 & 28.51 & 19.26 & 37.41 \\
\hline Some post secondary & 52.15 & 60.96 & 33.74 & 22.61 & 48.08 \\
\hline University degree & 83.70 & 95.45 & 44.49 & 36.93 & 72.92 \\
\hline Total Education & 46.55 & 63.81 & 33.66 & 20.77 & 46.45 \\
\hline \multicolumn{6}{|l|}{ British Columbia } \\
\hline 0 - 8 years & 52.71 & 45.61 & 26.22 & 18.26 & 25.07 \\
\hline $9-13$ years & 48.05 & 59.33 & 29.19 & 16.41 & 40.69 \\
\hline Some post secondary & 62.34 & 69.86 & 29.40 & 16.57 & 49.76 \\
\hline University degree & 77.53 & 86.77 & 29.57 & 18.78 & 60.02 \\
\hline Total Education & 54.74 & 70.22 & 29.17 & 17.07 & 46.72 \\
\hline
\end{tabular}

Note: Out-migration rate is calculated, for each age group and education level, by dividing the number of out-migrants by the population at risk (i.e., population plus out-migrants minus in-migrants),

and then multiplying the result by 1000 .

Source: Special tabulations from 2001 Census.

CSP 2007, 34.2: 129-148 
Educatiional Selectivity of Out-migration in Canada: 1976-1981 to 1996-2001

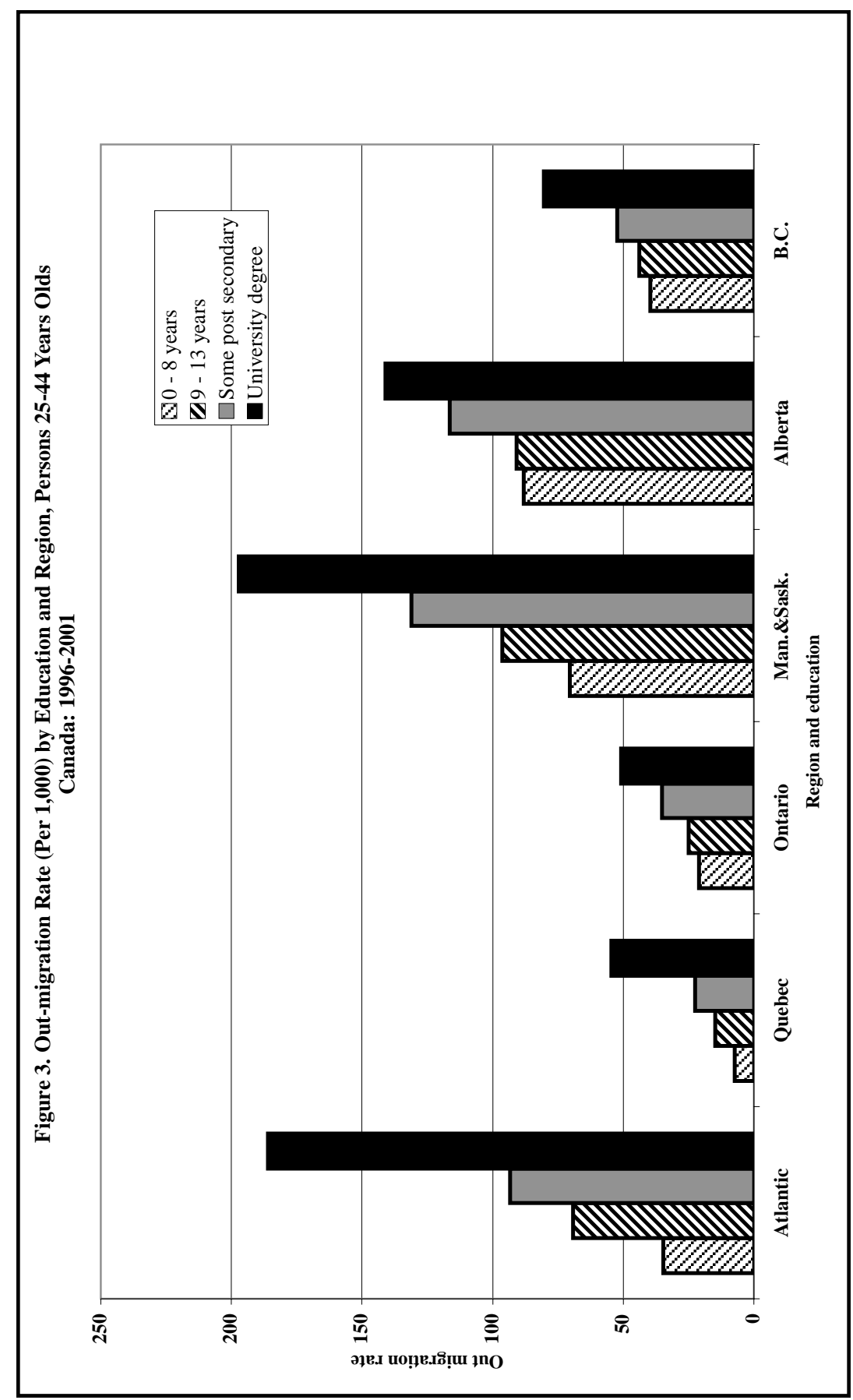

CSP 2007, 34.2: 129-148 
westward migration in response to the oil boom in Alberta, although it still remained the lowest of the regions during that period. During the period under study, British Columbia had only one experience of net loss, during 1996-2001, when its out-migration of the university educated rose, but still remained relatively low. The Alberta pattern falls in the middle, with its out-migration of university educated people being somewhere between 100 and 150 per 1,000. Even during the periods (1981-86 and 1986-91) when this province experienced net losses, its out-migration of university educated people did not rise much above that during its economic boom (1976-81).

As mentioned earlier, the migration experiences of the province of Quebec are unique. Unlike other regions, cultural-political factors have always played an important role in attracting or pushing people out of this province. An analysis of migration patterns in the province of Quebec without taking its linguistic composition into account would be incomplete. Thus, as expected, out-migration of the university educated persons in this province was most pronounced for Anglophones, particularly during 1976-81, a period of political turbulence. During this period, university educated Allophones (persons whose mother tongue is other than English or French) also experienced relatively high outmigrations.

These observations become clearer when we examine migration patterns by taking the ratio of the out-migration rate of the university educated persons to that of persons with less than grade 9 education. As shown in Figure 5, the ratio is highest in the province of Quebec. In this province, the out-migration rate of the university educated was about eight to nine times higher than that of the least educated during 1976-81 and 1981-86, the periods when the province lost its largest number of people. The rate declined during the periods that followed, although it again rose during 1996-2001. It is important to note, however, that this type of comparison without taking linguistic composition into consideration presents a misleading picture of migration patterns in the province of Quebec. Thus, when the ratio of the out-migration rate of the university educated persons to that of persons with less than grade nine within a specific linguistic group was calculated, the pattern was not as pronounced. These observations are in line with the findings of Robinson and Tomes (1982). The ratio is lower for the Atlantic region at about five and for Manitoba and Saskatchewan at about four.

Ontario is the next in order. During 1976-81 when the province experienced its largest net loss through out-migration in the wake of Alberta's oil boom, the outmigration rate of the university educated was only three times higher than that of the least educated. Since then, the ratio has been reduced substantially. Even during 1991-96 when Ontario experienced a net loss, the ratio was only slightly above two, lower than that for all regions but Alberta and British Columbia. 
Educatiional Selectivity of Out-migration in Canada: 1976-1981 to 1996-2001

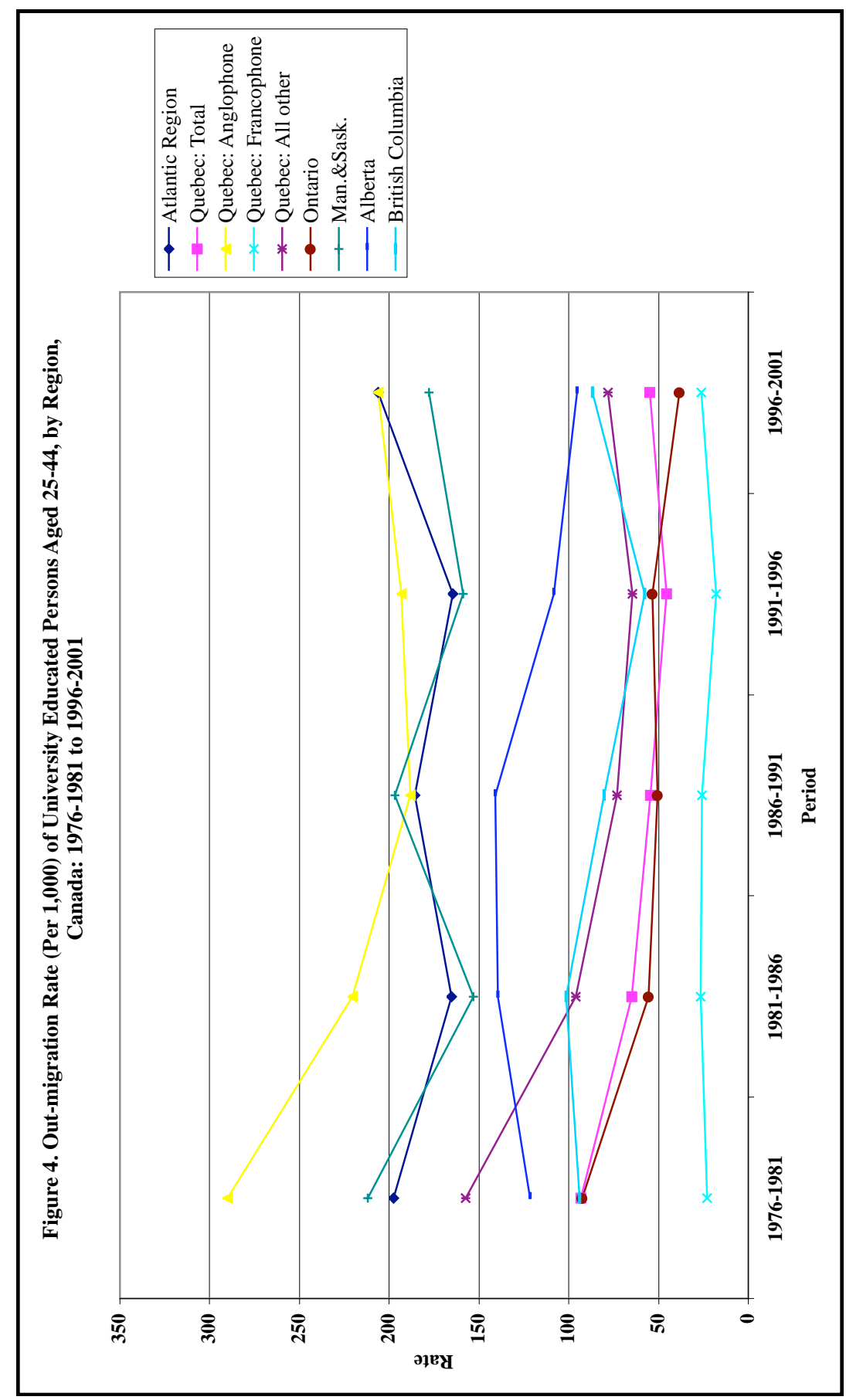

CSP 2007, 34.2: 129-148 
Bali Ram and Y. E. Shin

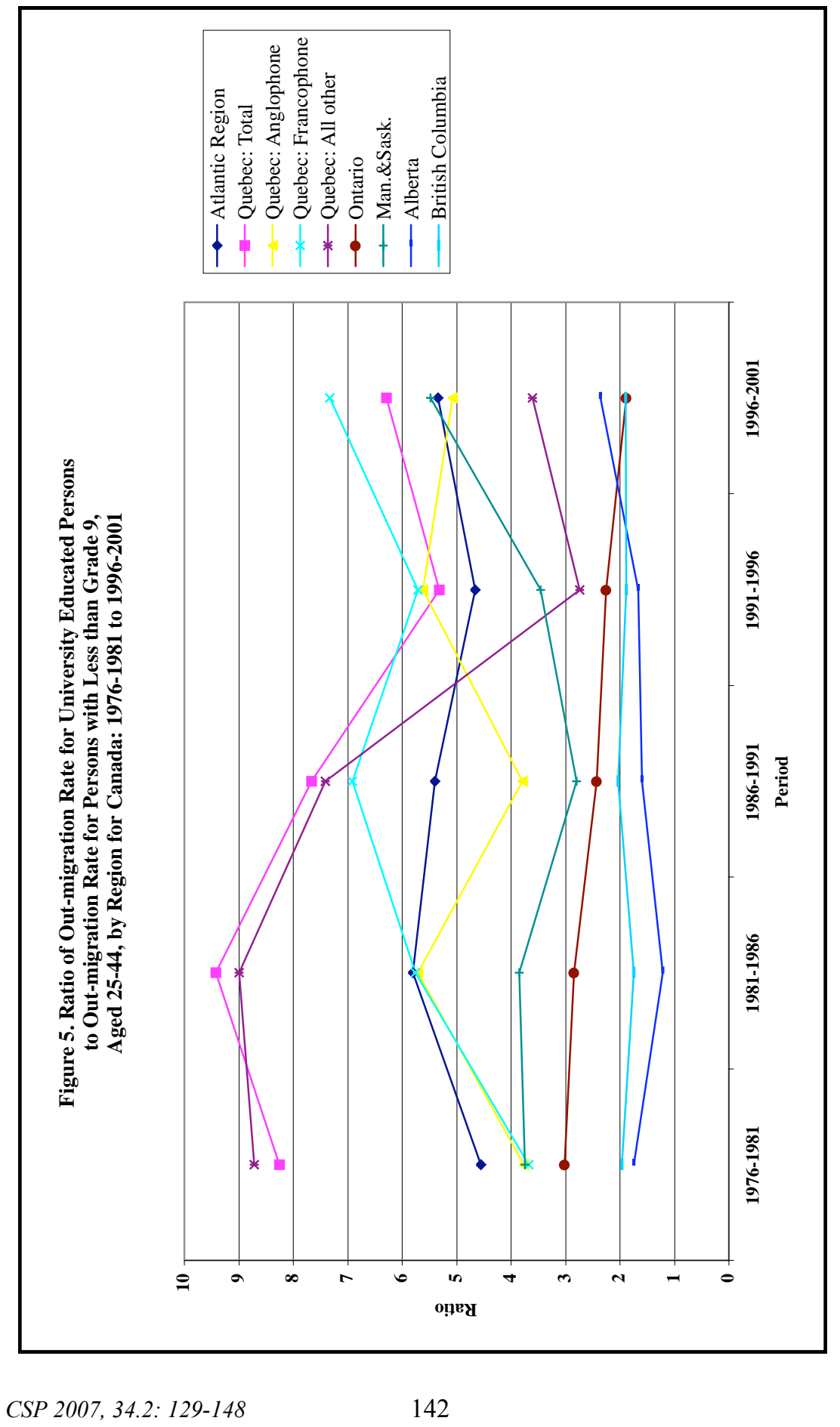


The ratio of the out-migration rate of the most highly educated to that of the least educated has usually been the lowest in Alberta, hovering around two during the period under study. Surprisingly, the ratios were relatively high in 1976-1981 and 1996-2001, the two intercensal periods when the province attracted the largest number of migrants, whereas the picture reversed in 198691 following the slump in its oil industry. In general, the province tended to lose persons of all characteristics, both highly educated and least educated, which has resulted in a lower educational selectivity. There was a marked stability in the educational selectivity of migrants in British Columbia. During both economically good times and bad times, the ratio of the out-migration rate for the university educated to that of the least educated remained virtually stable around two.

\section{Conclusion}

In migration literature, the evidence on the relevance of pushing forces of socioeconomic development at the place of origin is rather thin. Previous studies have found that actual out-migrations or expectations about future migration are weakly related to the social and economic climate of the place of origin. Migrants do not necessarily come from economically depressed areas. If anything, economically depressed regions have a slightly lower rate of outmigration than economically affluent regions (Lansing and Muller, 1967; Greenwood, 1985; Shaw, 1985:145). This observation is largely correct, if one ignores migrants' characteristics. In this study, we show that places which suffer from chronic economic stagnation or declines tend to induce out-migration of their better educated at a higher rate. It happens because these regions fail to provide the competitive educational opportunities and occupational skills needed by residents to take advantage of opportunities elsewhere (Lansing and Morgan, 1967). In fact, migration is most likely to occur between places which are vibrant centres of economic growth (Lansing and Muller, 1967). These hypotheses largely explain why the Atlantic region, Quebec, and Manitoba/Saskatchewan experience lower overall migrations but high outmigrations of the most highly educated, while Ontario, Alberta and British Columbia experience high overall migrations, but relatively low out-migrations of the most highly educated. Hou and Beaujot (1995) reached a similar conclusion in their study of migration between Ontario and Atlantic Canada during 1981-1991.

In summary, there are three broad patterns of migration selectivity in Canada. First, when regions are faced with chronic uncertainty-whether it is economic or noneconomic - they tend to lose their better educated people. Since highly educated persons in these regions may not be optimistic about their future, they 
are likely to move out to the regions which provide them with better hope for the future. This pattern characterizes migration patterns in the Atlantic region, Quebec, and Manitoba/Saskatchewan. In spite of an economic upsurge during the latest quinquennial period -1995-2000—under study, these regions kept on losing their populations through out-migration of the better educated. However, the migration pattern for the province of Quebec occupies a unique place because of cultural and political factors, in addition to economic conditions (Day and Winer, 2001; Milne, 1993; Robinson and Tomes, 1981). The selectivity hypothesis applies primarily to the linguistic minorities of this province, who are more likely than Francophones to move out, whenever they find themselves in vulnerable economic-political situations. The second pattern characterizes migratory behaviours in Ontario and Alberta. Although the economic climate in these provinces has been relatively volatile, they shown signs of speedy recovery. Even during unfavourable economic climates, people are likely to be hopeful for an economic turnaround. Consequently, the educational selectivity of migrants is not as pronounced there as in the former group. The third pattern characterizes British Columbia where people are less likely to be highly concerned about their uncertain economic future. Consequently, there is least selectivity of migrants.

An implication of the selectivity of migrants is for regional disparities that have historically existed in Canada, since only a few regions gain through the migration of educated and skilled persons at the expense of most others. Highly educated and skilled persons are more likely to move to vibrant regions with numerous and highly paid jobs, while less educated and less skilled people are either more likely to move to regions where lower-paying jobs are concentrated or stay where they are. Various programs and policies such as employment insurance (formerly unemployment insurance), resource industry adjustment programs and social assistance are designed to affect directly or indirectly the distribution of employment and work incentives, and reduce regional economic disparities. We might then ask: do these programmes and policies encourage the less educated, less skilled, and unemployed to stay in the regions of high unemployment and low incomes rather than to move to the regions with greater employment opportunities? Or conversely, do they discourage the better educated, more skilled and employed from not staying or from entering into the less developed regions? Detailed analyses on the relationship between public policy and interregional migration are required before any policy recommendations can made on the appropriateness of migration as a vehicle for improving the economic climate of chronically impoverished regions and for reducing regional disparities and on the appropriateness of public policies for directing specific kinds of migrations to specific regions. 


\section{Acknowledgements:}

This paper draws heavily on our earlier presentations at the annual meetings of the Population Association of America, Los Angels, California, March, 2000 and the Canadian Population Society, Winnipeg, Manitoba, June 2004. We are thankful to Réjean Lachapelle and the two anonymous referees for their comments on the earlier versions of this paper. The opinions expressed in this paper are ours, and do not necessarily reflect the views of Statistics Canada.

\section{End Notes:}

1. Quality of migrants is usually defined in terms of better human capital characteristics, such as education and skills.

2. Since migration data used in this paper are derived by comparing the respondent's place of residence on the census day and the place of residence five years ago, migrations which took place during these two dates are not captured. Thus, the census provides an underestimate of the actual migration during the intercensal period. More complete and annual data on internal migration for Canada are obtained from tax files. Based on these files, the Longitudinal Administrative Database ("LAD") has now become available (see, Finnie, 1999). However, census is perhaps the best source for studying migration trends and patterns by education and other characteristics.

\section{References:}

Blau, P. M. and O. D. Duncan. 1967. The American Occupational Structure. New York: John Wiley.

Cadwallader, M. 1992. Migration and Residential Mobility: Macro and Micro Approaches. Madison, Wisconsin: University of Wisconsin Press.

Courchene, T. J. 1974. 1970. "Interprovincial migration and economic adjustment,” Canadian Journal of Economics 3: 550-76.

Courchene, T. J. 1974. Migration, Income and Employment: Canada, 1965-68. C. D. Howe Research Institute.

DaVanzo, J. 1978. "Does unemployment affect migration?--evidence from micro data." Review of Economics and Statistics 60: 504-14. 
Bali Ram and Y. E. Shin

DaVanzo, J. 1983. "Repeat migration in the United States: Who moves back and who moves on," Review of Economics and Statistics 60: 504-514.

Day, K. M. and S. L. Winer. 2001. Policy-induced Migration in Canada: An Empirical Study. Ottawa: Human Resources Development Canada.

Finnie, R., 1999. "The patterns of inter-provincial migration in Canada 1982-95: Evidence from longitudinal tax-based data," Canadian Studies in Population 26: 205-234.

Finnie, R. 2000. "Who moves? A panel logit model analysis of inter-provincial migration in Canada." Research Paper No. 142. Business and Labour Market Analysis Division, Analytical Studies Branch, Statistics Canada.

Greenwood, M.J. 1997. "Internal migration in developed countries." In M. R. Rosenweig and O. Stark (eds.), Handbook of Population and Family Economics. Amsterdam: Elsevier. Pp. 647-720.

Greenwood, M.J. 1985. "Human migration: theory, models, and empirical studies," Journal of Regional Science 25: 521-44.

Greenwood, M.J. 1975. "Research on internal migration in the United States, a Survey," Journal of Economic Literature 13: 397-433.

Hou, F. and R. Beaujot. 1995. "A study of interregional migration between Ontario and Atlantic Canada: 1981-1991," Canadian Journal of Regional Science 28: 147-160.

Lansing, J. B. and E. Muller. 1967. The Geographic Mobility of Labor. Ann Arbor, Michigan: Survey Research Center, University of Michigan.

Lansing, J. B. and J. Morgan. 1967. "The effect of geographic mobility on income," Journal of Human Resources 2: 449-460.

Lee, E. S. 1966. “A theory of migration,” Demography 3: 47-57.

Levy, M. B. and W. J. Wadycki. 1974. "Education and the decision to migrate: An econometric analysis of migration in Venezuela," Econometrica 42: 377-388.

Long, L. H. 1973. "Migration differentials by education and occupation: Trends and variations." Demography 10: 243-258. 
Long, L. H. 1988. Migration and Residential Mobility in the United States. New York: Russell Sage.

Marmen, L. and J-P. Corbeil. 2004. Languages in Canada: 2001 Census. Ottawa: Statistics Canada.

Marr, W. L. and F.W. Millard. 1980. "Employment income levels of interprovincial migrants versus non-migrants, Canada, 1971." In J. Simon and J. DaVanzo (eds.), Research in Population Economics Vol. 2, JAI Press, Greenwich, CT.

McInnis, R.M. 1969. "Provincial migration and differential economic opportunity." In L.O. Stone, Migration in Canada: Regional Aspects. Ottawa: Dominion Bureau of Statistics. Pp. 131-202.

Milne, W.J. 1993. “ Macroeconomic influences on migration,” Regional Studies 27: 365-373.

Ram, B., Y. E. Shin, and M. Pouliot. 1994. Canadians on the Move. Focus on Canada Series, 1991 Census of Canada. Statistics Canada and Prentice Hall.

Ram, B. and Y. E. Shin. 2000. "Migration of Linguistic Groups between Quebec and Ontario, 1971-76 to 1991-96.” Paper presented at the annual meeting of the Population Association of America, Los Angeles, California.

Ravenstein, E. 1889. “The laws of migration," Journal of Royal Statistical Society 52: 241-301.

Ritchey, P. N. 1976. "Explanations of migration," Annual Review of Sociology. Pp. 363-404.

Robinson, C. and N. Tomes. 1982. "Self-selection and interprovincial migration," Canadian Journal of Economics 15: 474-502.

Sahota, G. S. 1968. "An economic analysis of internal migration in Brazil," Journal of Political Economy 76: 218-245.

Schwartz, A. 1971. "On efficiency of migration," Journal of Human Resources 6: 193-205. 
Bali Ram and Y. E. Shin

Schwartz, A. 1973. "Interpreting the effect of distance on migration," Journal of Political Economy 81: 701-719.

Schwartz, A. 1976. "Migration, age, and education," Journal of Political Economy 84: 701-719.

Shaw, R. P. 1975. Migration Theory and Fact. Philadelphia: Regional Science Research Institute.

Statistics Canada. 2004. Income in Canada, 2002. Catalogue 75-202-XIE. Ottawa: Statistics Canada.

Stone, L.O. 1969. Migration in Canada: Regional Aspects. Ottawa: Dominion Bureau of Statistics.

Stone, L. O. 1979. Occupational Composition of Canadian Migration. Ottawa: Statistics Canada.

Stone, L. O. 1978. The Frequency of Geographic Mobility in the Population of Canada. Ottawa: Statistics Canada.

Sjaastad, L. A. 1962. "The costs and returns of human migration," Journal of Political Economy 70: 80-93.

Vanderkamp, J. 1973. Mobility Behaviour in the Canadian Labour Force. Special Study No. 16. Ottawa: Economic Council of Canada. 